\title{
Is the Franco-German Relationship Still the Foundation Stone of the EU?
}

\author{
Abigail Leblanc \\ The University of Melbourne \\ abmleblanc@gmail.com
}

\begin{abstract}
Since the signing of the European Coal and Steel Treaties, France and Germany have been linked as unlikely friends in Europe. This paper discusses the Franco-German relationship post WWII, defining the characteristics of a partnership that has defined the history of the European Union and has served as a foundation for peace and cooperation on a continent that has struggled to shake off constant war. This paper then analyzes the hypothesis that the Franco-German relationship is no longer the foundation stone of the European Union in two sections. First, this paper applies these characteristics of deepening integration, increased economic interaction and mutually beneficial cooperation to the present day EU and seeing whether they are still integral to interactions among member states. It then establishes the present day characteristics of the EU as ones of increased national sovereignty, as opposed to Franco-German methods of cooperation.
\end{abstract}

\section{Introduction}

In January of 2019, Angela Merkel and Emmanuel Macron signed the Treaty of Aachen, a treaty reaffirming the Franco-German friendship and relationship of cooperation established in the Elysée Treaty 56 years earlier. Among the opening clauses is the affirmation that "the close friendship between Germany and France has been decisive for a united, efficient, sovereign and strong European Union and continues to be an indispensable element" ${ }_{1}$, and numerous allusions in the sixteen page document are made to increased cooperation in forming European Union policy and its institutions. The 2017 election of Macron signaled a newfound French commitment to EU integration, and a willingness to rejoin Germany as a central figure in the EU. However, despite these reaffirmations, the characteristics of the Franco-German relationship that were the foundation stone of the European Union in its early days have been weakening. Factions of the European Union have been moving away from the goals of deep integration that have characterized the two nations, leading us to question if the FrancoGerman relationship still exists as a foundation stone of the European Union. This paper will first establish the key characteristics of the Franco-German relationship as it exists in the post WWII era and analyze whether those characteristics can be accurately described as foundational for the European Union of today. This will bring us to the ultimate conclusion that, due to the changing nature of European politics and the

\footnotetext{
1 "Treaty between the Federal Republic of Germany and the French Republic on Franco-German Cooperation and Integration", Opened for signature January 22nd, 2019. France Diplomatie, https://www.diplomatie.gouv.fr/en/country-files/germany/france-and-germany/franco-german-treaty-of-aachen/. Introduction.
} 
incentives of today's member states, the Franco-German relationship is no longer the foundation stone for the European Union.

\section{Characteristics of the Franco-German Relationship}

Historically, the Franco-German relationship has consisted of a deep level of mistrust leading to war. However, through processes of European and bilateral integration, France and Germany have become deeply linked partners to each other. The development of the Franco-German relationship, through the European Coal and Steel treaties, into a relationship of reliance directly lead to the formation of the European Union. This section will explain the characteristics of the Franco-German relationship as the initial foundation stone of the European Union, and how the relationship presents itself today.

The first characteristic of the Franco-German relationship is a mutual push for deepening integration within Europe. Since the end of World War Two, both nations have realized the necessity of unions linking both each other together to maintain peace on the continent ${ }_{2}$, and have been the key architects of proposals to bring forth bodies like the European Union and its predecessors. This effort began with the creation of the European Coal and Steel Community in 1952. It included the Benelux countries and Italy but was primarily designed to link the German and French coal and steel economies, two industries necessary for war, to each other to make it economically disastrous for conflict to begin between the $\mathrm{two}_{3}$. France and Germany were also fundamental in the creation of the Maastricht Treaty, the effective birth of the European Union in its modern form negotiated primarily by Helmut Kohl and Francois Mitterrand 4 . This characteristic has not always been universal; Germany has shown more of an eagerness to integrate Europe while France has historically held more reservations. The two nations have often disagreed with the specifics of this integration; disagreement over the direction of the European Monetary Union at Maastricht was the primary stall in reaching economic integration ${ }_{5}$, with Germany being more eager to achieve political union and France solely focusing on monetary union 6 . With the election of Macron, however, both countries have leaders that are committed to deeper European integration. The Treaty of Aachen is yet another reaffirmation of this goal, showing that even in 2019, this remains a fundamental characteristic of the relationship.

The next characteristic of the Franco-German relationship to note is a deep level of economic interaction. France and Germany were among the first advocates for deeper economic unions within the European community throughout the 1970s, such as a European Monetary System, forming a new level of economic integration both with each other but also all of the European Community. Even today, the French and German

2 Stefanova, Boyka. The Europeanisation of Conflict Resolutions. Manchester: Manchester University Press, 2011. 50-51.

3 “The European Coal and Steel Community." Carleton University Center for European Studies.

Carleton University, n.d. https://carleton.ca/ces/eulearning/history/moving-to-integration/the-european-coal-andsteel-community/.

4 Baun, Michael J. “The Maastricht Treaty as High Politics: Germany, France, and European Integration.” Political Science Quarterly 10, no. 4 (1995): 605-24. https://www.jstor.org/stable/2151886. 616.

5 Yeong, Loke Hoe. "50 Years of the 'Twin Engine'." EU Centre in Singapore, March 2013. http://www.eucentre.sg/wp-content/uploads/2013/o6/BBo8-50yearstwinengine.pdf. 10.

6 Baun, Michael J. "The Maastricht Treaty as High Politics." 611.

7 Mourlon-Droul, Emmanuel. "Rethinking Franco-German Relations: a Historical Perspective.” Bruegel, no. 29 (November 2017). 
economies are incredibly dependent on each other; Germany is France's top trading partner 8 and France is within Germany's top three ${ }_{9}$. While France and Germany have been at odds over how to achieve this in some cases, economic interdependence has been seen by both nations as a method of ensuring peace and cooperation. With the agreement to form an economic union as part of the Maastricht Treaty, the FrancoGerman relationship again succeeded at establishing a foundation stone of economic integration with the aforementioned dispute over the extent of political union solved by compromise $_{10}$. This economic aspect remains at the forefront of Franco-German relations today, with Aachen's largest tangible goal being deeper establishment of a joint economic area on the Franco-German border ${ }_{11}$.

The previous two characteristics are policy based, but the final key characteristic of the Franco-German relationship is a value based one. The Franco-German relationship has gone from one of mistrust to one of a deep commitment to peace through cooperation, equality and reconciliation of past hostilities. This has come through efforts to link the nations together culturally through government promotions of student exchanges and

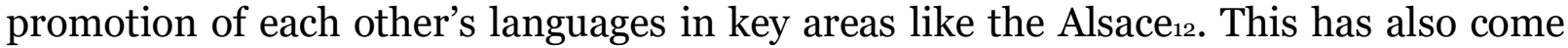
through symbolic acts between the two leaders, who have engaged in occasionally confrontational but usually close relationships since WWII. The image of Kohl and Mitterrand holding hands at a war memorial in 1984 is an enduring image of this reconciliation $_{13}$. Elysée mandated meetings at regular intervals between the leaders of each country ${ }_{14}$, who have often found compromise in varying and often contrasting policy goals together. The Franco-German relationship is defined by a realization that the maintenance of peace and stability in Europe is contingent on the continued cooperation of the French and German governments.

\section{Present-Day Characteristics of the European Union}

The Franco-German relationship will always be tied to the formations of the European Union and will help in explaining its founding principles. Recent trends indicate, however, that Europe may be moving in a new principled direction, or that the stability of the European Union may be under threat. This section will compare the state of the European Union today to the fundamental characteristics of the Franco-German relationship outlined above.

One sign that this relationship may no longer be the foundation stone of the European Union is the increasing ambivalence towards deeper integration from member states. There is the obvious case of Brexit, a state removing itself entirely from the European Union. However, even among states that traditionally joined Franco-German efforts for deeper integration, there are rising Eurosceptic forces, with states wanting back

\footnotetext{
http://bruegel.org/wp-content/uploads/2017/11/PC-29-2017.pdf.

8 "France." OEC, n.d. https://oec.world/en/profile/country/fra/.

9 "Ranking of Germany's Trading Partners in Foreign Trade." Destatis Statistiches Bundesamt, August $19,2019$. https://www.destatis.de/EN/Themes/Economy/Foreign-Trade/Tables/order-rank-germany-tradingpartners.pdf;jsessionid=8932822C2FC01A8BBF7670FAE6324B67.internet741? _ blob=publi cationFile. 10 Baun, Michael J. "The Maastricht Treaty as High Politics”. 616.

11 Mcintosh, Jane. “What's in the Franco-German Treaty of Aachen?” DW.COM. Deutsche Welle, January 22, 2019. https://www.dw.com/en/whats-in-the-franco-german-treaty-of-aachen/a-47178247.

12 Yeong, Loke Hoe. "50 Years." EU Centre in Singapore, March 2013.

13 Helmut Kohl and François Mitterand in Verdun. Photograph. GHDI. Verdun, n.d. German Information Center. http://ghdi.ghi-dc.org/sub_image.cfm?image_id=2472.

14 Yeong, Loke Hoe. “50 Years.”
} 
unilateral control over their affairs. Italy and Hungary have formed an alliance of sorts over this principle, both with Eurosceptic governments and populations who want to take back control over immigration ${ }_{15}$, opposed to Germany's integrationist approach of dividing refugees among member states. Approval ratings among European citizens are at a high, but $50 \%$ of respondents in the 2019 Eurobarometer said they felt like things were not going right either in the EU or their own country ${ }_{16}$, as even European citizens have questions about the Union. This is a weakening of the foundation stone of progressive European integration that is fundamental to the Franco-German relationship.

Economic integration and stability in the European Union have also been weakened, and the troubled state of the Eurozone has brought up questions over whether the Franco-German engineered plan of a monetary union is a successful one. The Eurozone crisis was the first of the monetary union, and nearly lead to Greece having to pull out after amassing historically high levels of debt ${ }_{17}$. It was feared Greece pulling out could lead to the collapse of the entire Eurozone, due to the levels of financial dependence the union created ${ }_{18}$. While multiple German-lead bailouts and austerity policies were able to stabilize the situation, they were deeply unpopular throughout Europe and called into question the benefit of the union ${ }_{19}$. With rising unemployment rates and high risk of continued financial crisis in Southern Europe, the viability of the Eurozone continues to be at risk.

Both of these characteristics bring into question whether the Franco-German relationship remains the foundation stone for the modern EU. On the value-based principle, however, the Franco-German relationship still holds some weight. The United Kingdom leaving brought renewed unity among the 27 remaining member states, affirming together the benefits of the EU membership that the United Kingdom would be forfeiting. Brexit brought a rare unity, with member states agreeing that "there will be no separate negotiations between individual Member States and the United Kingdom on matters pertaining to the withdrawal of the United Kingdom from the Union" 20 , agreeing to work together to solve the economic and political hardships Brexit would visit on them. This normative principle has remained such a fundamental part of the character of the EU that other member states have expressed their displeasure with the reaffirmations of the Franco-German relationship like the Aachen Treaty. European Council President Donald Tusk warned the two countries that "enhanced cooperation in

\footnotetext{
15 Giuseppe, Lisa Di. "Italy and Hungary Vow to Work Together on Hardline Approach to...” Reuters. Thomson Reuters, August 28, 2018. https://www.reuters.com/article/us-italy-hungary/italy-and-hungary-vow-to-worktogether-on-ha rdline-approach-to-migrants-idUSKCN1LD2DD.

16 "Support for EU Remains at Historically High Level despite Sceptics.” European Parliament, European Parliament, April 25, 2019. http://www.europarl.europa.eu/news/en/press-room/20190417IPR41755/support-for-euremainsat-historically-high-level-despite-sceptics.

17 Hotten, Russell. "Greece Takes the Eurozone's Future to the Brink." BBC News. BBC, June $21,2011$. https://www.bbc.com/news/business-13842763.

18 ibid.

19 “Timeline: The Unfolding Eurozone Crisis.” BBC News. BBC, June 13, 2012. https://www.bbc.com/news/business13856580 .

${ }_{20}$ "European Council (Art 50) guidelines for Brexit negotiations". European Council, April 29. https://www.consilium.europa.eu/en/press/press-releases/2017/04/29/euco-brexit-guidelines/.
} 
smaller formats is not an alternative to the cooperation of Europe as a whole"..21 There does, to an extent, remain a desire to cooperate as a foundation stone of the EU.

However, even on the principle of unity and cooperation, there are questions over whether this can be considered a foundation stone in times of crises. The 2015 refugee crisis showed an astounding lack of unity among member states and resulted in mostly unilateral action 22 . Unlike the Franco-German relationship, unity and compromise seem to have eroded as a foundation stone when national interests become important among many member states. This highlights the changing face of the European Union. While France and Germany rightfully see themselves as dependent on each other for ensuring prosperity, there is much less of this sentiment from other member states. Slovakia does not necessarily feel the need to cooperate with Belgium, for example, on policy to ensure its survival. The foundation stone of the European Union has changed because of the widening of integration and the changing dynamics at play. There is no need for cooperation among many of the member states to prevent another world war.

\section{Conclusion}

There is no question about the continued importance of the Franco-German relationship within the two countries for economic and political stability. The two nations have been linked through their economic and political policies and will likely continue a close cooperation for years to come. However, as a result of other metrics, that relationship is no longer the foundation stone of the European Union. Member states are much more likely to want to preserve national sovereignty instead of acquiescing to wide sweeping legislation about integration, and the Eurozone is still a volatile experiment that may struggle to survive debt crises in Southern Europe. The spirit of cooperation and negotiation to come to multilateral decisions does remain to an extent, and there is a level of European unity shown by member states, but even the extent of that is called into question when member states refuse to cooperate on massive humanitarian crises. The foundation stone of the European Union is unclear in 2019. It is perhaps a union to counter American influence. However, unless behaviours shift dramatically during the next European crisis, or war threatens the European Union into closer dependency and integration, the Franco-German relationship is no longer the foundation stone of the European Union. It is, however, the foundation stone of Germany's and France's nationhood and prosperity.

\section{Bibliography}

Baun, Michael J. “The Maastricht Treaty as High Politics: Germany, France, and European Integration.” Political Science Quarterly 10, no. 4 (1995): 605-24. https://www.jstor.org/stable/2151886.

Burchard, Hans von der. "Macron and Merkel's Treaty Tests European Nerves." Politico. April 18, 2019. https://www.politico.eu/article/emmanuel-macron-andangela-merkel-franco-german-aach en-treaty-tests-european-nerves/.

\footnotetext{
${ }_{21}$ Burchard, Hans von der. "Macron and Merkel's Treaty Tests European Nerves." Politico, April $18,2019$. https://www.politico.eu/article/emmanuel-macron-and-angela-merkel-franco-german-aachen-treaty-testseuropean-nerves/.

22 Perre, Nick, Myrtha de Vries, Hannah Richards, and Mariana Gkliati. "Refugee Crisis: Three Perspectives on the Makings of the Crisis. " Oxford Law Faculty, June 12, 2018. https://www.law.ox.ac.uk/research-subjectgroups/centre-criminology/centreborder-criminologies/blog/2018/o6/refugee-crisis.
} 
"European Council (Art. 50) guidelines for Brexit negotiations". European Council, April 29, 2017. https://www.consilium.europa.eu/en/press/press-releases/2017/04/29/euco-brexit-guidelin es/ "France.” OEC, n.d. https://oec.world/en/profile/country/fra/.

Giuseppe, Lisa Di. "Italy and Hungary Vow to Work Together on Hardline Approach to...” Reuters. Thomson Reuters, August 28, 2018, https://www.reuters.com/article/us-italy-hungary/italy-and-hungary-vow-to-work-together -on-hardlineapproach-to-migrants-idUSKCN1LD2DD.

Helmut Kohl and François Mitterand in Verdun. GHDI. Verdun, n.d. German Information Center. http://ghdi.ghi-dc.org/sub_image.cfm?image_id=2472.

Hotten, Russell. "Greece Takes the Eurozone's Future to the Brink.” BBC News. BBC, June 21, 2011. https://www.bbc.com/news/business-13842763.

Mcintosh, Jane. "What's in the Franco-German Treaty of Aachen?” DW.COM. Deutsche Welle, January 22, 2019. https://www.dw.com/en/whats-in-the-francogerman-treaty-of-aachen/a-47178247.

Mourlon-Droul, Emmanuel. "Rethinking Franco-German Relations: a Historical Perspective.” Bruegel, no. 29 (November 2017). http://bruegel.org/wpcontent/uploads/2017/11/PC-29-2017.pdf.

Perre, Nick, Myrtha De Vries, Hannah Richards, and Mariana Gkliati. "Refugee Crisis: Three Perspectives on the Makings of a Crisis.” Oxford Law Faculty, June 12, 2018. https://www.law.ox.ac.uk/research-subject-groups/centre-criminology/centrebordercriminologies/blog/2018/o6/refugee-crisis.

"Ranking of Germany's Trading Partners in Foreign Trade." Destatis Statistiches Bundesamt, August 19, 2019. https://www.destatis.de/EN/Themes/Economy/Foreign-Trade/Tables/order-rank-germanytrading-partners.pdf;jsessionid=8932822C2FCo1A8BBF7670FAE6324B67.internet741?__blob=publicationFile.

Stefanova, Boyka. The Europeanisation of Conflict Resolutions. Manchester: Manchester University Press, 2011.

"Support for EU Remains at Historically High Level despite Sceptics." European Parliament, European Parliament, April 25, 2019, http://www.europarl.europa.eu/news/en/-press-room/20190417IPR41755/support-for-eu-re mains-at-historicallyhigh-level-despite-sceptics.

"The European Coal and Steel Community." Carleton University Center for European Studies. Carleton University, n.d. https://carleton.ca/ces/eulearning/history-/movingto-integration/the-european-coal-and-ste el-community/.

“Timeline: The Unfolding Eurozone Crisis.” BBC News. BBC, June 13, 2012. https://www.bbc.com/news/business-13856580.

Yeong, Loke Hoe. “50 Years of the 'Twin Engine'.” EU Centre in Singapore, March 2013. http://www.eucentre.sg/wp-content/uploads/2013/o6/BBo850yearstwinengine.pdf. 